\title{
Correlation between Maxillary Central Incisor Crown Morphology and Mandibular Dental Arch Form in Normal Occlusion Subjects
}

\author{
Luiz Renato PARANHOS ${ }^{1}$ \\ Carolina Souto LIMA ${ }^{2}$ \\ Ricardo Henrique Alves da SILVA ${ }^{3}$ \\ Eduardo DARUGE JÚNIOR ${ }^{4}$ \\ Fernando Cesar TORRES 5
}

\author{
${ }^{1}$ Department of Oral Biology, Dental School, USC - Sagrado Coração University, Bauru, SP, Brazil \\ ${ }^{2}$ Department of Orthodontics, School of Health, UMESP - Methodist University of São Paulo, \\ São Bernardo do Campo, SP, Brazil \\ ${ }^{3}$ Department of Forensic Dentistry, Ribeirão Preto Dental School, \\ USP - University of São Paulo, Ribeirão Preto, SP, Brazil \\ ${ }^{4}$ Department of Public Health, Piracicaba Dental School, UNICAMP - University of Campinas, Piracicaba, SP, Brazil \\ ${ }^{5}$ Department of Pediatric Dentistry and Orthodontics, UNICID - University of São Paulo City, São Paulo, SP, Brazil
}

\begin{abstract}
The aim of this study was to evaluate the correlation between the morphology of the mandibular dental arch and the maxillary central incisor crown. Cast models from 51 Caucasian individuals, older than 15 years, with optimal occlusion, no previous orthodontic treatment, featuring 4 of the 6 keys to normal occlusion by Andrews (the first being mandatory) were observed. The models were digitalized using a 3D scanner, and images of the maxillary central incisor and mandibular dental arch were obtained. These were printed and placed in an album below pre-set models of arches and dental crowns, and distributed to 12 dental surgeons, who were asked to choose which shape was most in accordance with the models and crown presented. The Kappa test was performed to evaluate the concordance among evaluators while the chi-square test was used to verify the association between the dental arch and central incisor morphology, at a 5\% significance level. The Kappa test showed moderate agreement among evaluators for both variables of this study, and the chi-square test showed no significant association between tooth shape and mandibular dental arch morphology. It may be concluded that the use of arch morphology as a diagnostic method to determine the shape of the maxillary central incisor is not appropriate. Further research is necessary to assess tooth shape using a stricter scientific basis.
\end{abstract}

Key Words: form perception, tooth, dental arch.

\section{INTRODUCTION}

Facial beauty can be defined as a state of balance and harmony among facial features and it is influenced by several factors. Its concept is subjective and has followed the development of civilizations (1). Certain combined factors should be considered when discussing appearance and smile aesthetics. A harmonious and natural smile is important in achieving a pleasant face. As the face, dental morphology has also been studied with the objective of standardizing tooth shapes in order to improve the diagnosis and execution of treatment plans (2).
Genetic factors exert great influence on characteristics such as tooth shape and dental arch form. Genetic mechanisms are clearly predominant during craniofacial morphogenesis; however, external environmental factors can also influence the determination of these traits, particularly during the growth stage (3). Size and morphology of the basal bones are influenced by genetics and have a polygenic heritage. Genes is responsible for determining a given group of characteristics. Whenever one of these genes is modified, the remaining others would be influenced and altered as well. Therefore, tooth size and dental arch 
form, among other traits, are genetically determined by many genes from the parents $(3,4)$.

In the early 20 th century, tooth shape was classified according to facial shape, but inverted, and teeth were grouped according to different geometric shapes: square, triangular and oval (5). This classification contributed somewhat to the creation of complete dentures.

The correct choice of artificial tooth size begins by selecting the size and width of the six anterior maxillary teeth, although there is no consensus among authors (6) regarding the existence of methods for such selection. In clinical settings for all dental specialties, it is essential to use the correct proportion between teeth and face, in order to make forms more balanced and harmonious. During oral rehabilitation, it is fundamentally important to know the anatomical traits of the arches and dental crowns, particularly while selecting artificial teeth for a total prosthesis. The dentist's work is simple when the patient has photographic records previous to the extractions; the lack of a record prior to teeth extraction hinders the reproduction of the size of the anterior dental segment for a fully edentulous mouth. Thus, we sought with this work to verify the correlation between maxillary incisor shape and mandibular arch form in order to facilitate the production of complete dentures.

\section{MATERIAL AND METHODS}

Fifty-one cast models from Caucasian individuals older than 15 years with healthy teeth and normal occlusion were used. All patients had at least 4 of the 6 keys to normal occlusion by Andrews, with the first key being regarded as essential for sample selection. Patients with craniofacial malformations, facial asymmetries and odontogenic anomalies were excluded from the sample as well as models featuring lab errors and fractured teeth.

The cast models were digitized using a 3D scanner (dw5-140; Dental Wings, Montreal, Quebec, Canada). The captured images were automatically processed using Dental Wings software, generating a ".stl" file for each model. Then, the maxillary incisor and mandibular dental arch images were captured using the Print Screen keyboard command and exported to CorelDRAW X3 (Corel Corporation, Ottawa, ON, Canada) vectoring software, in which they were cropped. Considering the morphology of the dental arch, the references were the
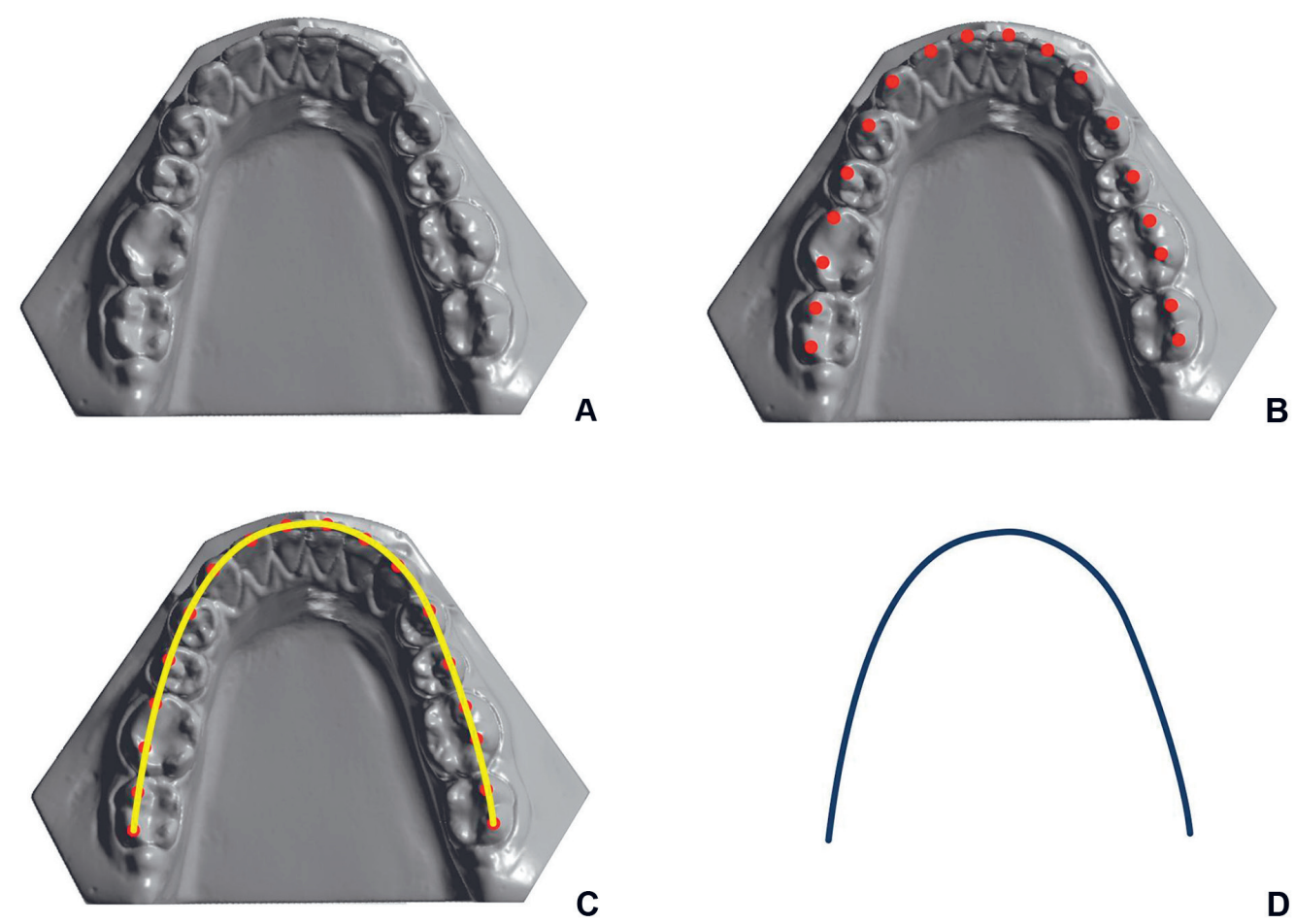

C

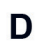

Figure 1.3D scans of the mandibular arch. $A=$ Arch exported; $B=$ Marking of the incisal edge of the incisors and cusp tip of mandibular canines, premolars and molars; $\mathrm{C}=$ Demarcation of Angle's line of occlusion; $\mathrm{D}=$ Final morphology of the mandibular dental arch. 
incisal edge of the incisors, cusp tip of the canines, buccal cusp tip of the premolars and molars, thus establishing Angle's line of occlusion (Fig. 1). In order to improve visualization, the image of the right maxillary central incisor was resized to $10 \mathrm{~cm}$ and set in negative, with a dark background, in order to improve visualization (Fig. 2).

After that, the images were printed in the center of a $90 \mathrm{~g} / \mathrm{m}^{2}$ white paper, below pre-set models of arches and dental crowns, as previously reported (2). Each sheet showed the tooth models classified as square, oval and triangular, as well as the arches with the same denominations. All images of the arches and crowns were then distributed separately to 12 dentists, who were requested to indicate the most closely form that resembled the models of arches and crowns. After 1 week, the answers were collected.

To evaluate method error, a second analysis was carried out by 3 dentists chosen at random. The approximated interval between the first and second analysis was 2 weeks. To verify system and casual errors, the paired t-test and Dahlberg's error formula were used, respectively. To verify the concordance of the classification of the dental arch and the morphology of the central incisor, among examiners, the Kappa test was used and interpreted according to Landis and Koch (7). To verify the correlation between arch form and incisor morphology, chi-square was performed.

A 5\% significance level was adopted for all tests and calculations were made using Statistics for Windows ${ }^{\mathrm{TM}}$ version 5.1 (StatSoft Inc., Tulsa, OK, USA).

\section{RESULTS}

System and casual errors tests showed no statistically significant results, demonstrating a good reliability of the method $(p<0.05)$. The result of the Kappa test showed significant concordance for both arch form and tooth shape, being greater for the $\operatorname{arch}(\mathrm{k}=0.55)$ than for teeth $(\mathrm{k}=0.52)(\mathrm{p}<0.05)$. According to Landis and Koch (7), the concordance value was "moderate" for both arch and teeth.

Arch forms and tooth shapes were chosen according with the most part of the evaluators opinions, once the objective was not to calculate an average, but to relate one kind of arch with one kind of tooth shape.

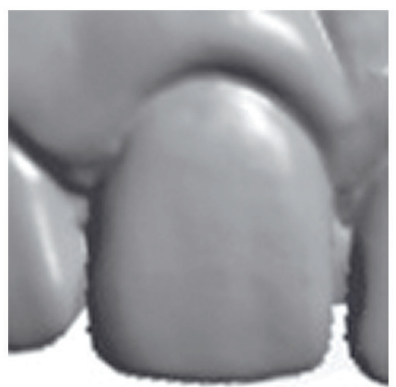

A

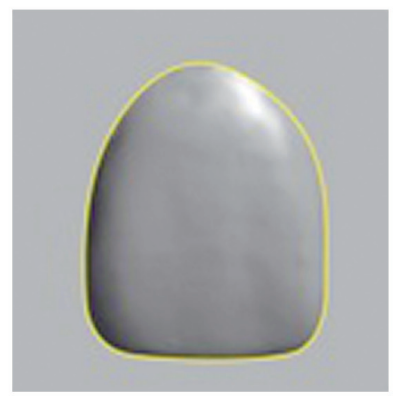

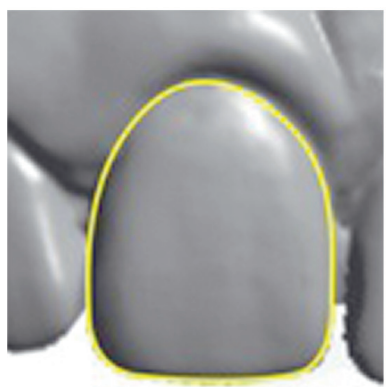

B

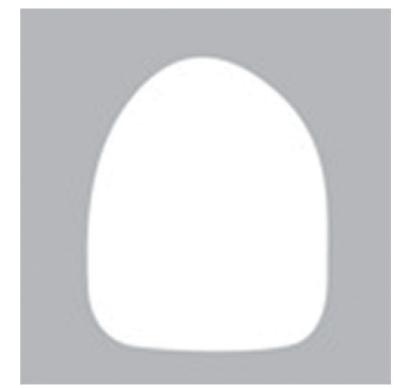

C

Figure 2. 3D scans of the maxillary right incisor. $A=$ Tooth exported; $B=$ Delimitation of tooth morphology; $C=$ Isolated image of the incisor crown; $\mathrm{D}=$ Negative image of the crown. 
The chi-square test showed no statistically significant correlation between arch form and tooth shape, as shown in Table $1(\mathrm{p}=0.480)$. The prevalent form for both teeth and arch morphology was the oval.

\section{DISCUSSION}

Several methods have been applied to choose the ideal tooth shape, particularly maxillary incisors in totally edentulous patients $(5,8,9)$. The relationship between teeth and other facial structures has already been studied, but the only significant finding was that there are an appropriate ratio between the dimensions of a patient's hard palate with the sum of six maxillary frontal teeth (10). In addition, some authors $(11,12)$ have found a possible association between tooth shape and dental arch form, and are constantly seeking for a more efficient and reliable method to choose the shape of artificial teeth during the construction of total prostheses.

Patient oral rehabilitation must take into consideration factors such as shape, placement and color of the maxillary central incisors; these are key characteristics to obtain an aesthetically harmonious smile (13), contributing to improve the facial balance. Nevertheless, sex, age, ethnicity and even the personality and aesthetic wishes of each patient must be considered.

In the present study, the morphology of the maxillary central incisor was mostly oval $(47.06 \%)$, followed by square $(31.37 \%)$ and triangular $(21.57 \%)$ (Table 1). This prevalence of maxillary central incisor morphology was evaluated in a recent study of our

Table 1. Correlation between mandibular dental arch form and maxillary central incisor shape.

\begin{tabular}{|c|c|c|c|c|c|}
\hline \multirow{2}{*}{ Arch form } & & \multicolumn{3}{|c|}{ Tooth shape } & \multirow{2}{*}{ Total } \\
\hline & & Oval & Square & Triangular & \\
\hline \multirow{2}{*}{ Oval } & $\mathrm{n}$ & 11 & 8 & 2 & 21 \\
\hline & $(\%)$ & (52.4) & (38.1) & $(9.5)$ & (100.0) \\
\hline \multirow{2}{*}{ Square } & $\mathrm{n}$ & 8 & 6 & 6 & 20 \\
\hline & $(\%)$ & $(40.0)$ & $(30.0)$ & $(30.0)$ & (100.0) \\
\hline \multirow{2}{*}{ Triangular } & $\mathrm{n}$ & 5 & 2 & 3 & 10 \\
\hline & $(\%)$ & $(50.0)$ & $(20.0)$ & $(30.0)$ & $(100.0)$ \\
\hline \multirow{2}{*}{ Total } & $\mathrm{n}$ & 24 & 16 & 11 & 51 \\
\hline & $(\%)$ & $(47.1)$ & (31.4) & $(21.6)$ & (100.0) \\
\hline
\end{tabular}

$\chi^{2}=3.48 ; p=0.480$. research group (2). This is likely due to characteristics of the sample, such as gender, and the evaluation methodology. For women, the oval (round) or square shapes should be preferentially chosen and, for men, rectangular with rounded edges (square-round) is the most common (14). Moreover, women have teeth with different size than men (15). The aesthetic perception of lay people and dentists using photographs to associate the smile with maxillary central incisor shape was also evaluated (16). The photos were altered to show 3 different tooth shapes (square, conic and oval), associating them with each facial contour, totaling 18 images. The oval-shaped tooth was the most popular among dentists, but there was no concordance between the shapes of the face and the maxillary central incisor.

Izard (17) has stated that dental arch width has a positive correlation with facial width and that the dimensions of the dental arches are compatible with the different facial types. Individuals with a shorter face (brachyfacial) tend to have excessively broad arches, while the opposite occurs with dolichofacial individuals $(18,19)$. Regardless of morphologic variety, there seems to be a direct relationship between tooth size and arch size $(15,20)$, considering that broad maxillary and mandibular dental arches usually have larger teeth $(11,12)$ and that ethnic differences influence the size and shape of teeth and arches $(21,22)$.

The present study did not find an association between arch morphology and tooth shape. Nevertheless, it is interesting to notice that the oval tooth shape was the most prevalent in oval-arch individuals. These results is in agreement with those of other authors $(13,23)$ and diverge from the study of Al-Khatib et al. (15). This difference may be due to ethnical differences of the samples, as well as the characteristic of the occlusion. Other studies that found correlation used the measurements of other anatomical landmarks, such as face length (24), inverted facial shape, bizygomatic distance (25), pterygomaxillary notches (8), as well as different methods of image classification and analysis.

Sellen et al. (13), using a sophisticated method of image superimposition, analyzed the correspondence of 4 aesthetic values: face shape, tooth shape, dental arch form and palatal contour form. The most significant correspondence was between arch form and facial shape $(28 \%)$, followed by a low correspondence $(24 \%)$ between dental arch form and tooth shape. Some years later, Berksun et al. (23), using standardized digital photographs, attempted to verify a subjective correlation 
between face shapes, dental arches and tooth shape, and found that the correlation between the face and dental arch was $54 \%$, followed by face and tooth (51\%), and arch and tooth (46\%). Examiners showed unsatisfactory concordance. In the present study, the result of the Kappa test showed a statistically significant agreement both for arch form and tooth shape, being higher for arch than teeth. According to Landis and Koch (7), the concordance value was "moderate" for both variables.

It may be concluded that the use of arch morphology as a diagnostic method to determine the shape of the maxillary central incisor is not appropriate. Therefore, further studies must be done to assess tooth shape using a stricter scientific basis.

\section{RESUMO}

O objetivo deste estudo foi avaliar a correlação entre a morfologia do arco dental mandibular e da coroa do incisivo central maxilar. Para isso, foram avaliados modelos em gesso de 51 indivíduos, leucodermas, com idade acima de 15 anos, com oclusão ótima, sem tratamento ortodôntico prévio, que deveriam apresentar 4 das 6 chaves de oclusão de Andrews (sendo a primeira indispensável). Estes modelos foram digitalizados em 3D e foram obtidas imagens tanto do incisivo central quanto do arco dental. As imagens foram impressas e dispostas em uma folha, abaixo de modelos pré-estabelecidos de arcos e de coroas dentais, e distribuídos para 12 cirurgiões-dentistas, que foram convidados a escolher o formato que mais estivesse em conformidade com os modelos e coroas apresentados. Foi realizado o teste Kappa para avaliar a concordância entre os avaliadores, enquanto o teste do quiquadrado foi utilizado para verificar a associação do arco dental e do incisivo central, com nível de significância de 5\%. O teste Kappa mostrou concordância moderada entre os examinadores para as variáveis deste estudo, e o teste do qui-quadrado mostrou não haver associação estatisticamente significante entre a forma do dente e do arco dental mandibular. Pode-se concluir que a utilização da morfologia do arco como método diagnóstico para determinar a forma do incisivo central maxilar não é apropriada. Pesquisas adicionais são necessárias para avaliar a forma do dente utilizando ciência baseada em evidência.

\section{REFERENCES}

1. Basciftci FA, Uysal T, Buyukerkmen A, Demir A. The influence of extraction treatment on Holdaway soft-tissue measurements. Angle Orthod 2004;2:167-173.

2. Paranhos LR, Jóias RP, Velasco L, Bérzin F, Daruge Júnior E. Prevalence of the different maxilary central incisor in individuals with natural normal occlusion. Braz J Oral Sci 2010;2:104-107.

3. Mossey PA. The heritability of malocclusion: Part 1 - Genetics, principles and terminology. Br J Orthod 1999;2:103-113.

4. Mossey PA. The heritability of malocclusion: Part 2 - The influence of genetics in malocclusion. Br J Orthod 1999;3:195203.

5. Williams JL. A new classification of human tooth forms, with special reference to a new system of artificial teeth. Dental Cosmos
1914;5:627-628.

6. Engelmeier RL. Complete-denture esthetics. Dent Clin North Am 1996;1:71-84.

7. Landis JR, Koch GG. The measurement of observer agreement for categorical data. Biometrics 1977;1:159-174.

8. Guldag MU, Buyukkaplan EUA, Sentut F, Ceylan G. Relationship between pterygomaxillary notches and maxillary anterior teeth. J Prosthodont 2010;19:231-234.

9. Mahshid M, Khoshvaghti A, Varshosaz M, Vallaei N. Evaluation of "golden proportion" in individuals with an esthetic smile. J Esthet Restor Dent 2004;3:185-192; discussion 93.

10. Petricević N, Katunarić M, Mehulić K, Simeon P, Rener-Sitar $\mathrm{K}$, Celebić A. Selection of appropriate artificial frontal teeth size using dimensions of hard palate. Coll Antropol 2006;30:573-577.

11. Burris BG, Harris EF. Maxillary arch size and shape in American blacks and whites. Angle Orthod 2000;4:297-302.

12. Collins BP, Harris EF. Arch form in American blacks and whites with malocclusions. J Tenn Dent Assoc 1998;1:15-18.

13. Sellen PN, Jagger DC, Harrison A. Computer-generated study of the correlation between tooth, face, arch forms, and palatal contour. J Prosthet Dent 1998;2:163-168.

14. Anderson KM, Behrents RG, McKinney T, Buschang PH. Tooth shape preferences in an esthetic smile. Am J Orthod Dentofacial Orthop 2005;4:458-465.

15. Al-Khatib AR, Rajion ZA, Masudi SM, Hassan R, Anderson PJ, Townsend GC. Tooth size and dental arch dimensions: a stereophotogrammetric study in Southeast Asian Malays. Orthod Craniofac Res 2011;14:243-253.

16. Jon LYTC, Morante DRH, Bernabé E, Vich MOL, Cotrina LAD. Esthetic perception towards different combinations of facial contours and upper incisor shape. Braz J Oral Sci 2009;4:193-196.

17. Izard G. New method for the determination of the normal artch by the function of the face. Int J Orthod 1927;13:582-595.

18. Kageyama T, Dominguez-Rodríguez GC, Vigorito JW, Deguchi T. A morphological study of the relationship between arch dimensions and craniofacial structures in adolescents with Class II Division 1 malocclusions and various facial types. Am J Orthod Dentofacial Orthop 2006;3:368-375.

19. Ricketts R. Provocations and perceptions in cranio-facial orthopedics, dental science and facial art. Denver: Rocky Mountain Orthodontics, 1989

20. Lee SJ, Lee S, Lim J, Parque HJ, Wheeler TT. Method to classify dental arch forms. Am J Orthod Dentofacial Orthop 2011;140:8796.

21. Ferrario VF, Sforza C, Colombo A, Carvajal R, Duncan V, Palomino H. Dental arch size in healthy human permanent dentitions: ethnic differences as assessed by discriminant analysis. Int J Adult Orthodon Orthognath Surg 1999;2:153-162.

22. Nojima K, McLaughlin RP, Isshiki Y, Sinclair PM. A comparative study of Caucasian and Japanese mandibular clinical arch forms. Angle Orthod 2001;3:195-200.

23. Berksun S, Hasanreisoglu U, Gokdeniz B. Computer-based evaluation of gender identification and morphologic classification of tooth face and arch forms. J Prosthet Dent 2002;6:578-584.

24. House M, Loop JL. Form and color harmony in the dental arch [monograph]. Whittier: California; 1937.

25. Sears VH. Selection of anterior teeth for artificial denture. J Am Dent Assoc 1941;28:929-935.

Received December 21, 2010 Accepted December 13, 2011 